This is an electronic version of an article published as: Warsh, C.K. (2006). The Canadian Cigar and Tobacco Journal in the forties: A remembrance. Social History of Alcohol and Drugs: An Interdisciplinary Journal, 21(1), 23-49.

Social History of Alcohol and Drugs: An Interdisciplinary Journal is published by the Alcohol and Drug History Society and is available online at: https://alcoholanddrugshistorysociety.org/shadjournal/

This article is available at:

https://alcoholanddrugshistorysociety.files.wordpress.com/2010/11/shad-21-1-warsh.pdf. 


\title{
THE CANADIAN CIGAR AND TOBACCO JOURNAL IN THE FORTIES:A REMEMBRANCE
}

\author{
Cheryl Krasnick Warsh
}

\begin{abstract}
This paper is a period snapshot of the life and times of Canadian smoking culture, filtered through The Canadian Cigar and Tobacco Journal (the industry's trade paper) from 1943-1949. The Journal provided a vivid portrait of neighbourhood tobacconists, travelling salesman, wholesalers and factory workers, homemakers and entrepreneurs. I discuss the role of Jews in the industry, as manufacturers and retailers. The Journal evokes the dangers of the retail trade, such as armed robberies, as well as the dangers of wartime. There is also the parallel danger of tobacco smoking, which, although not explicitly defined as risky behaviour by physicians, nonetheless is apparent to consumers. World War II is a dominant feature of The Journal, and the celebration of wartime tobacco consumption is epitomized by Winston Churchill and other heroic smokers. Women's increased economic participation during the war years, and postwar demobilization, is reflected in The Journal. Finally, I discuss the growing targeting of children as potential consumers of tobacco.
\end{abstract}

A few years ago, while searching for background on the Canadian tobacco industry, I was generously directed by Jarrett Rudy ${ }^{1}$ to The Canadian Cigar \& Tobacco Journal (hereafter The Journal) the trade paper for the growers, manufacturers, wholesalers and retailers who comprised the Canadian tobacco industry, centred primarily in southern Ontario and Quebec. The Journal was established by Harry Gagnier in 1894. It was part of the Consolidated Press group which published Saturday Night, Canadian Home Journal and Farmer's Magazine, among others. With its head office in Toronto, it maintained branches in Montreal, New York, Vancouver and Los Angeles, and published articles, news items, federal tobacco consumption reports and current trade prices, as well as stories of local interest to the various parts of the trade. Most of the advertisements originated in Montreal or Toronto, since the Canadian tobacco farms and manufacturers were located in southern Quebec and Ontario.

Perhaps here, I thought, would be the "smoking guns." Would I find evidence of a Canadian industry "conspiracy" to promote nicotine consumption parallel to the actions of the giant American tobacco manufacturers as outlined in Stanton Glantz's The Cigarette Papers?2 I chose the period 1943-

Cheryl Krasnick Warsh is Professor of History at Malaspina University College in Nanaimo, British Columbia. 
1949 which would encompass Canada's periods of full mobilization during World War II, and immediate post-war readjustments, since the forties saw peaks of both tobacco consumption among men and women and positive popular imaging of the habit. ${ }^{3}$ I did not find many smoking guns, although I did find evidence of some used shells of marketing strategies. I also found a vivid portrait of a world of neighbourhood tobacconists, travelling salesmen, Jewish wholesalers and Québecois factory workers, homemakers and entrepreneurs - in short, a portrait of the world of my father. ${ }^{4}$ This paper will be a period snapshot in the life and times of Canadian smoking culture, filtered through The Journal.

I will discuss the roles that Canadian Jews played in various aspects of the industry, including manufacturing and sales. Although a tiny percentage of the national population, the concentration of Jews in the retail trades and in the tobacco centres of Montreal and Toronto provided them with more positive visibility in The Journal than in other contemporary periodicals. One of the most evocative aspects of The Journal's content is a sense of danger; armed robberies of smoke shops frequently were recorded, as were, by the end of the war, reports of salesmen or family members killed in combat overseas. Yet there also was the danger associated with tobacco consumption, and I analyze how the industry's publication dealt with health concerns in a period when smoking purportedly was not recognized as risky behaviour. These risks were overshadowed by the immediate dangers of the war, but surfaced in the post-war issues. Before 1946, however, a nation mobilized for war was apparent in the ads, articles and other features, and smoking was advanced as a metaphor for comradeship, courage under fire, and patriotism, and personified by many heroes, none of whom eclipsed Winston Churchill. The war was also the age of heroines, as women took on public and private roles in the national emergency. This transformation was apparent in The Journal, as women as manufacturers, growers, sellers and consumers of tobacco were front and centre, particularly in 1943 and 1944. With the first veterans returning home, however, there was a rapid and noticeable shift in the focus in the ads and articles from woman as active performer to woman as passive consumer (and producer of babies). The postwar baby boom was presented in The Journal as a marketing opportunity not only to promote domestic consumption of tobacco products, but to introduce a new generation to the habit.

\section{The Jewish Connection}

Although Jews comprised a tiny proportion of the Canadian population (1.5\% in 1941), their concentration in Montreal and Toronto ${ }^{5}$ was reflected in The Journal. ${ }^{6}$ On the humbler side was Montreal's I. Feldstein who advertised for damaged or discontinued merchandise such as lighter fluid and razor blades. More substantial was H. Simon and Sons of Montreal, who manufactured Simon's Havana's, La Florena and Pandora brands of cigars. ${ }^{7}$ The most illustrious figure was Sir Mortimer B. Davis, founder of Imperial Tobacco, who 
was no longer alive in the forties but whose shadow hung large over the industry and Montreal philanthropy. ${ }^{8}$ During the Depression, Maxie Blackstein catered to smokers who switched from cigarettes to tobacco and cigarette papers: "Many smokers sought a new source of supply... probably because they were a little ashamed of their financial position and did not wish to go to their regular retailer." There was a feature article in 1943 of Jack Lewis, an English-born Jewish tobacconist in Montreal. There were also several reports on Frank O'Brien Cohen, "both well known and highly esteemed" who operated O'Brien's cigar shop and sandwich counter in Rouyn, Quebec, until he sold it to Mrs. Steve Malouf, whose husband (likely a Lebanese-Canadian) was a Prisoner of War in Japan. In anticipation of his release, Mrs. Malouf renamed the shop, "Steve's Lunch Bar and Tobacco Store."

For the most part, The Journal was welcoming to their Jewish members in an anti-Semitic era, although there was evidence of exclusionary policies in the larger community. There were few Jewish participants pictured at the annual industry golf tournaments, held at restricted golf clubs. There were Jews pictured at the industry's Cedar Brae golf tournament in 1943, although they were photographed for the magazine with the pianist, apart from the other participants. In 1946, when members of two Jewish tobacco families from Montreal and New Brunswick married, the father of the bride sent in the notice with a poem. Even the romantically titled, "Tobacco Retailer Courts Girl by Mail," did not shy away from the terrible realities of the forties:

Several months ago Henry Goldstein, 36-year-old Ottawa tobacconist, saw a photograph of pretty 23-year-old Jolana Simkovicova of Prague, Czechoslovakia, in her aunt's home in Brooklyn, N.Y. She was a displaced person who had been in the Buchenwald concentration camp. Her parents were murdered there but she escaped and worked with the underground. He knew her parents slightly because he also came from that place. He wrote her immediately. Four months later, they were married in Ottawa where they now reside. ${ }^{10}$

Because there were many Jews in the retail trades, their presence was more apparent in trade magazines like The Journal than in general mass circulation periodicals in the Forties, and reflected the everyday encounters of members of Canada's multicultural cities. Yet not all of these encounters were welcomed.

\section{DANGERS OF STOREKEEPING}

The Journal recounted many incidents that plagued the tobacconists, especially robberies, which occurred coast to coast. ${ }^{11}$ In one of its "Maritime News" columns, The Journal reported thefts from unlocked tobacco trucks in Halifax and the seizure of stolen cigarettes from the jail cell of three "prisoners" in Amherst, Nova Scotia, who sawed off one of their cell windows and simply left when they wanted a "night off" from jail. Wartime brought additional problems, such as marauding veterans. In 1943, two soldiers forced a window in a Toronto smoke shop, but were frightened away by a woman sleeping in 
the back. When a minor crime wave hit Vancouver in the winter of 1943-44 due to a shortage of police, "soldier thieves in a liquor store" fought "bitterly with police" when they were captured. ${ }^{12}$ Then there was the disreputable side of the retail industry. Because smoke shops would sometimes be fronts for gambling operations, they were occasionally raided for illegal betting or housing slot machines. ${ }^{13}$ Yet there were other, less dramatic, dangers of the tobacco industry.

\section{MORTALITY $^{14}$}

Could the tobacconists and other readers of The Journal not 'know' that smoking was dangerous and addictive in the forties? ${ }^{15}$ Certainly there were hints that tobacco men didn't have a long life expectancy. The Canadian life expectancy for a 40 year old man in 1941 was 32 more years. ${ }^{16}$ That was not what The Journal's obituaries showed. In 1943, Carleton S. Richardson, the "popular" advertising president for W.C.MacDonald, died at 49, while John W. Weir, Alberta Manager of Tuckett Ltd., a tobacco distributor, passed away at 37 from pleurisy, leaving three children under ten years. Wholesaler Julius Rain died at 44, while M. Michaud, the President of House \& Grothe Tobacco, died at 53. Joseph Benoit of Imperial Tobacco died at 51, and many company representatives attended his funeral. Camille E. Poupart, well known Montreal tobacconist, died while vacationing in Old Orchard, Maine at $48 .{ }^{17}$ While certainly mortality and morbidity were ever-present for Canadians in the forties, the sum total of these notices of lives cut short, published on a monthly basis, must have led to some discomfort among readers.

They could find some comfort in the far less numerous, nonetheless impressive examples of the juxtaposition of smoking, athleticism and longevity. An inspirational news item was the victory of the "cigar-smoking runner ... Jaunty little Gerard Coté, 34-year-old special policeman from Quebec," who won his fourth Boston Marathon in 1948. Coté was a colourful character. Crossing the finish line, he "signalled to an onlooking bartender at his hotel to have a beer ready for him and 10 minutes after the race he was answering questions from behind a big cigar." In the face of new medical evidence of the hazards of tobacco, the article triumphantly ends, "Who said smoking ruins your wind?"18 Yet Coté was still only 34. Halifax's George A. Anderson offered these words on his milestone birthday: "You can reach the age of 90 by smoking to beat the band, but [stay] away from [alcohol]." 84-year-old Joseph A. Clink of Toronto, however, drank beer since he was twelve. "I started smoking a pipe when I was 14, and I've smoked it ever since. I probably have spent a lot of money on beer and tobacco, maybe more money than I have saved, but I always have believed that a man who lived without drinking beer or smoking a pipe didn't have much to live for." These words were echoed by James J. (Big Jim) Jeffries, former heavyweight boxing champion, when he was interviewed after suffering a stroke: "Guess I'm pretty lucky," said Jim, lighting up a cigar against his doctor's orders. "Yeah, I'm still smoking," he nodded. 
"If you can't enjoy a cigar once in awhile you might as well be dead."19 These words of resignation likely were echoed by other smoker-readers.

While smoking immediately post-stroke was too much for any physician to recommend, The Journal trotted out articles, with greater frequency by 1946, trumpeting the low risk, and even health benefits of smoking. These articles underlined the general anxiety growing about the habit. In 1943, Robert H. Feldt, Medical Director of Northwestern Mutual Life, countered (albeit ambivalently) the "myth" that smoking caused high blood pressure ("The best way to quiet nerves is smoking," but "See your doctor if you have high blood pressure or ulcer"); and that the "nursing mother [who] smokes too much [makes] her baby restless and irritable." Feldt concluded, "It is easy for reformers to dismiss the tobacco problem by saying, 'Smoking never did anyone any good,' but the satisfaction that millions of confirmed smokers derive from a cigarette, pipe or cigar must not be overlooked." This was faint praise indeed from the industry's best medical spokesman. Some articles were more obvious products of industry shills. The Medical Society of Virginia in 1944 claimed that "Nicotine is Made Harmless by Body," since it either was burned, went up in smoke, or was "altered" by the liver. In March 1946, there were three articles discussing the health risks or benefits of smoking, such as the use of tobacco leaf extract to fight hypertension. ${ }^{20}$

Yet it should not be assumed that medical advice in the forties was automatically accepted as expert advice. Following decades of imperfectly trained physicians with lofty rhetoric but often inadequate therapeutics, the general public might well be cynical. Cynicism certainly was evident in The Journal's news items and cartoons. Doctors were characterized as "commonly [being] heavy smokers" in the facetious piece, "Smokers Not So Bad After All," reprinted from The New York Times. ${ }^{21}$ With a "little ingenuity," the smoker could defend his health risks with the 'positives' that

He has almost no temptation ... to get under way too rapidly in the early hours of the day. Being placid and reflective rather than a man of action, he has little tendency to overdo physically. He starts his day with a measure of quiet thoughtfulness, good for his glands and easy on the heart. His taste for sweets is well under control, and if he reaches for a cigarette or his tobacco pouch instead of a cocktail glass, he may even do less drinking. Being a little short of breath, especially as the years wear on, he tends to preserve a wholesome tempo. If he springs less he does instead have more than time for meditation and the inner life, and correspondingly more energy to apply to his mental problems.

When C. A. Harris, London, Ontario's Medical Health Officer, opined that chewing tobacco was healthy because in smoking, "combustion is just about everything," even The Journal dismissed his arguments with the title, "Are you kiddin' Doc?" By the Forties, the tobacco companies themselves acknowledged health concerns; the back cover of the Journal issue featuring Harris's article was a Craven A ad with the new tag line, "will not affect your throat." 22

The most authoritative rebuttal to the anti-tobacco studies was "Is Tobacco 
Injurious?" by Irvin S. Koll, renowned attending urologist of Chicago's Michael Reese Hospital. Koll began his article, published in 1949, with a humorous anecdote about a young man who neither drank, smoke nor dated women, but wanted the secret to longevity. The "astounded medico" exploded, "Why, then, do you want to live to be a hundred years old?" Having said that, Koll changed gears and argued that the preponderance of evidence showed that "on the whole the use of tobacco in moderation is literally harmless" but a certain percent of individuals showed an "idiosyncrasy to nicotine." Koll argued that smoking had "never been known" to raise blood pressure or cause heart disease, it aided digestion, and, "if it produces irritation such as ... habitual coughing, then the use of tobacco should be either curtailed or stopped." ${ }^{23}$ Koll's article reflected the public concerns for "unrefined" or public display of bodily functions such as coughing or incessant throat clearing, rather than for the internal, invisible (and deadly) manifestations of heart disease. ${ }^{24}$ Did this comfort The Journal's reader-smokers? Or did they, like Koll's 'medico' or Big Jim Jeffries, resign themselves to their fates?

\section{WARTIME $^{25}$}

Such introspection had seemed superfluous in the black and white realities of the combat years. Images of war were ever-present in The Journal of the mid-forties.

MacDonald Tobacco, in its ad: "1943: Comes the Dawn," presented a montage of warplane, destroyer, tank, and large gun to both display its patriotism, and warn its readership about tobacco rationing and shortages: "Our Fighting Forces come first." Advertisements for accessories, such as Ronson lighters and Eddy Matches portrayed soldiers and promised to be handy in foxholes. By March 1943, Player's Navy Cut Cigarettes advertised its natural link to the war effort, with an expensive cover series, "Topsides goes to Sea for Player's to sketch the Canadian Navy in Action." Even the Kool penguin joined the infantry in a double-paged ad. ${ }^{26}$ When penguins ventured, women soon followed. Buckingham's two page billboard style spread displayed a young woman in uniform holding a package of smokes, while two Player's Tobacco ads of 1943 featured young WRENs (Figure 1). ${ }^{27}$

Sending tobacco to the troops overseas was a popular act, as it had been during World War I. In 1943, the British Columbian government sent 250,000 cigarettes to their forces in Britain for Christmas, as well as a carton to every B.C. resident who was a Prisoner of War. Canadian Legion branches across the nation also were commended for sending tobacco donations to the troops. ${ }^{28}$ By the winter of 1944, cigarettes and federal taxes upon them were directly linked to the war effort: A Canadian airman, stationed in England, stated, "What a difference to receive and smoke a good old Canadian fag." "Cigs... are one of the greatest morale builders and comforts that the men receive"-ranked second after letters from home. "Every time you light up a cigarette, Mr. Smoker, give yourself a pat on the back. You will have just contributed another cent to 
Figure 1. WRENs in a Player's ad

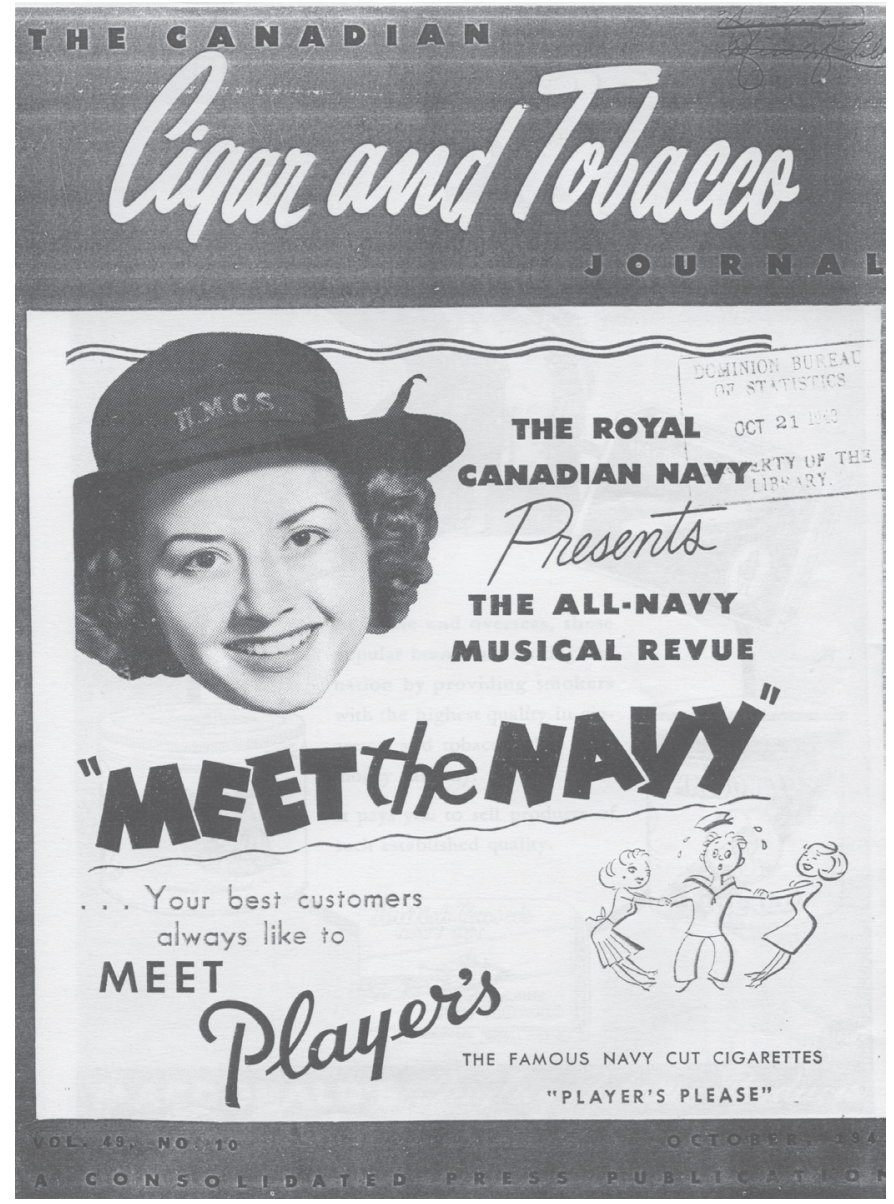

buy the implements of war. Supposing you to be quite a smoker-consuming 35-40 cigarettes a day... in two weeks you will have smoked enough to buy an anti-tank mine. In a year-enough for a 2" trench mortar and 25 trench mortar bombs. Then watch the Nazis smoke." 29

The Journal published several accounts linking tobacco with military comradeship and survival itself. When a soldier leaned forward to light a cigarette while filming the Sicily campaign, shrapnel hit the spot where his head had been and he narrowly escaped death. A Commander, rendered nearly blind from an insect bite in Africa and unable to read or write for three months, found that "cigarettes made life more bearable." A very effective feature was the photo series, "Smokers of the World," which in the early forties was tied to the war effort. In 1943, two (apparently) teen-aged Norwegian soldiers were pictured sharing a cigarette, as were the crew of H.M. Corvette Dianthus, which had sunk a u-boat in the North Atlantic. Nor were enlisted men 
the only smokers featured. In 1944, Air Chief Marshal Sir Sholto Douglas, head of RAF Coastal Command, was pictured lighting his pipe during the North African campaign. In an incident reprinted from the American service newspaper Star and Stripes, Allied soldiers were confronted by German counterparts who displayed their humanity by preferring American cigarettes. New Jersey-born Sgt. Arthur Holmes was confronted by a German soldier pointing a Luger at him on the Anzio beachhead. The soldier, in "perfect English," asked "Have you got a cigarette or two?" Holmes "unwillingly" gave him some, was thanked, and the German "disappeared in the nearby woods." That Holmes had to be "unwilling" to proffer the smokes in exchange for his life likely reflected an attempt to avoid a slight upon his courage..$^{30}$

Through these stories and images, the point was hammered home to the public that smoking together signified universal friendship and humanity, rendering the Second World War period the apex of tobacco's positive image. ${ }^{31}$ But the greatest benefit of the War was spelled out in 1944 in an article on post-war planning. "The war is doing something else, too, for the tobacco industry. It's teaching millions or more men to smoke. When they come home, you'll find them in the retail tobacco shops in greater numbers than ever before." ${ }^{32}$

\section{Popular Heroes of the Tobacco Trade}

Along with the rank and file, there were the special heroes of wartime (and post-war) smoking. It was clear from the pages of The Journal that the War could not be lost with a cigar smoker like Winston Churchill in command.$^{33}$ So devoted was Winnie to his cigar that doctors had to remove it from his mouth during a chest $\mathrm{x}$-ray for pneumonia. ${ }^{34}$ The British lion was also mildly rebuked for his smoking technique, since he worked "both ends at once." "I'll never forget the PM's cigars," remarked John Ruggles, the co-pilot of the Liberator that flew Churchill to Moscow. "He filled the plane so full of smoke that we had to open the bomb doors." ${ }^{.35}$ America's supreme commander, Franklin Delano Roosevelt, was not to be outdone by his British ally. When he underwent a thirty-minute operation, the surgeon had to refuse the chain-smoker a cigarette. Regardless of his other shortcomings (like committing genocide in Ukraine), Josef Stalin graciously accepted the pipes he was given by the American War Production Board. As "famous" war correspondent Quentin Reynolds stated, "Stalin is a very human man who, contrary to popular opinion smiles a great deal and is very jovial." ${ }^{36}$ The iconic smoking picture of the war has to be the Smokers of the World photo of May 1945, in which a pipe, a cigar and a cigarette in holder are displayed in an ashtray (Figure 2). So identified was smoking with the Allied leadership that general audiences would have known they were the property of Stalin, Churchill and Roosevelt (at Yalta). ${ }^{37}$ Churchill's hold as the Lion of Tobacco remained after the war and his administration. His successor Clement Attlee (Smoker of the World of 1945) was pictured with his pipe, since "One of the necessary qualifications 
Figure 2. "The cigarette is out."

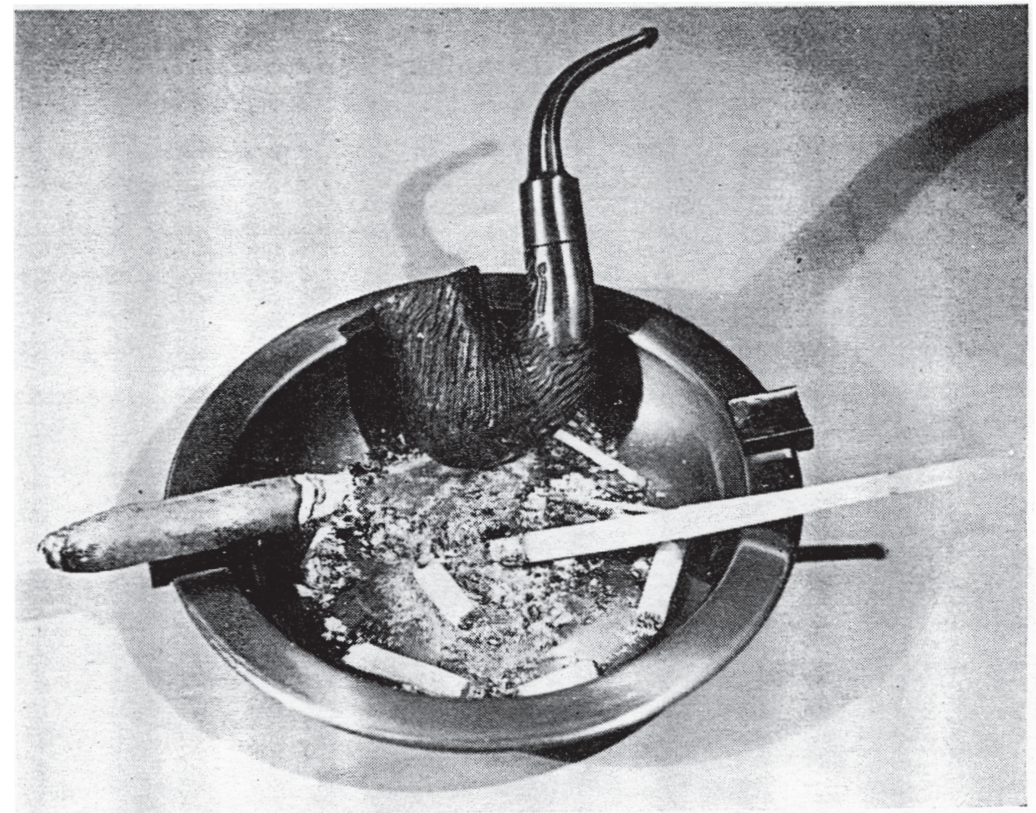

THE CIGARETTE IS OUT

America's beloved smoker is with us to more. The late President Roosevelt's long famous cigarette, has seen its last council table. The above mute witness to the comradeship existing among the three powers was taken at the Yalta conference of Roosevelt, Churchill and Stalin.

for the post of Prime Minister of Great Britain seems to be the ability to consume large quantities of tobacco in its various forms." 38

The Journal featured smoking icons, male, female and imaginary, although none matched the stature of Churchill. The loss of musical star Bing Crosby's extensive pipe collection to fire was noted along with Walt Disney Picture's cartoon "Saludos Amigos," which featured Joe Carioca, the cigar-smoking parrot. ${ }^{39}$ There were also reports of American tobacco manufacturers' promotional tie-ins with movies and radio programming. In 1943, the Cigar Institute of America (CIA) promoted a movie featuring Charles Coburn, a character actor who was always filmed with a cigar, quoting a newspaper article's "totally unreliable" statistic: "Coburn's vivid enjoyment of the weed, his soulful smile as Lady Nicotine soothes him and warms his inner being with gentle solace, has upped the sale of cigars 22.7 per cent in the past four years... Mr. C. habitually glowers at every human being in his casts, but his face softens and becomes paternal when he turns to his cigar." The Journal recommended that the movie be locally promoted. ${ }^{40}$ When wartime heroes weren't available, The Journal trotted out a photo of two actors staging the scene of Raleigh handing Lady Nicotine to Queen Elizabeth the First. ${ }^{41}$ While there is no evidence that that monarch ever took up the nicotine habit, other women would. 


\section{WOMEN AND TOBACCO}

That the smoke-shop was first established as male space was evident in the girly pictures and risqué jokes published in The Journal..$^{42}$ The girly pictures were relatively innocuous press photos of starlets from American movie studios (especially RKO and Paramount) which were published at the rate of 3-4 per month. ${ }^{43}$ They were not large prints, but they could be cut out and thumb tacked for the edification of barber shops' male customers. There were also photos of National Selective Service (NSS) women working in war plants. ${ }^{44} \mathrm{~A}$ magazine favourite was Yvonne de Carlo, who hailed from Vancouver. ${ }^{45}$

There also were somewhat more risqué jokes, for that nudge-nudge, winkwink sales transaction. "We want a girl to sell kisses at the bazaar. Have you had any experience?" "I went to college." "You're hired." ${ }^{47}$ There were hen-pecked husband jokes, dumb girl jokes, and jokes about shooting wives. ${ }^{48}$ "Daughter: I can't marry him, mother. He is an atheist and doesn't believe there is a hell. Mother: Marry him, my dear, and between us we will convince him that he is wrong." There were dirty old lady jokes: "Burglar: 'please let me go lady_-I never did anything wrong.' Old Maid: 'Well, it's never too late to learn." "49

Yet there were also signs that some of the conventions of a longstanding public male subculture were collapsing. During the war and post-war eras, women's place in the tobacco industry - in its manufacture, sale or consump-

Figure 3. Women making wartime cigarettes.

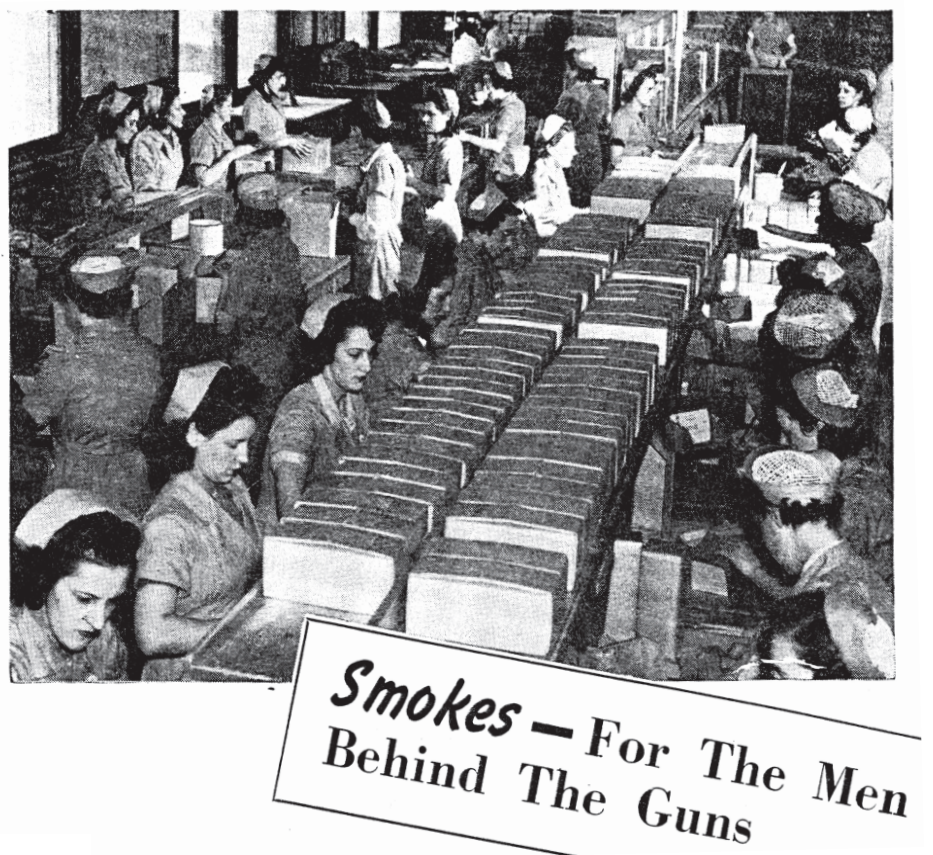


tion-was a dominant feature of The Journal. In terms of manufacturing, women have been associated with tobacco since Carmen left her Spanish tobacco-rolling plant to weave her seductive spell on soldiers and bullfighters. In a feature article on Toronto's Gregory Stuart Tobacco, licensee of the English Dunhill brand, photographs of the factory floor showed women cleaning the tobacco leaves, and folding and filling packages. Similarly, photographs of Montreal's Imperial Tobacco factory showed an all-woman labour force (Figure 3). ${ }^{50}$

Because of their long association with the industry, women were not as rapidly affected by post-war demobilization as in other economic sectors. Feature articles on cigarette, pipe and cigar factories, as well as tobacco farms, included photos that displayed the retention of a female workforce. "How Cigars are Made," for instance, displayed four women in the shop. ${ }^{51}$ Josephine Rapchak, a Delhi, Ontario tobacco grower, was featured in 1946. There also were women pictured at industry banquets, but compared to 1943 photos, there were less present, and most were 25 -year employees or the lone secretary at the head table. ${ }^{52}$ Significantly, those employees tended to be unmarried women, whose lives were unencumbered by children. A striking deviation from prewar photographs of women in tobacco plants was the Rock City photo spread of 1947, where the all-female crew were working under the watchful gaze of a man standing at the end of the table, arms folded in a dominant position (Figure 4). By 1948, a woman's place in industry photographs was as Miss Tobacco Leaf. This winner of an in-house beauty contest is flanked by Governor-General Alexander and company president Earle Spafford, reflecting the importance of the company in the Canadian economy, rather than her value as worker on the shop floor. ${ }^{53}$

Figure 4. Rock city tobacco women

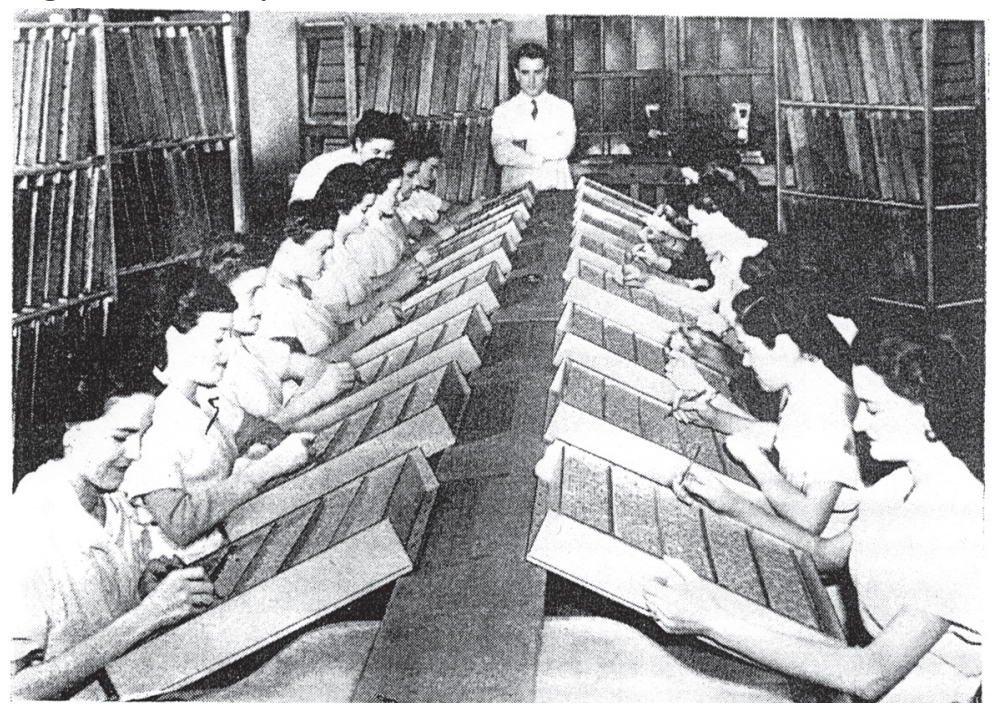


During the war, there was a heightened presence of women in the retail trade as well. When A. Mally of Kamloops went on active service in 1942, Miss Flora Zingrich took over his store. In 1943, tobacconist Jack Lewis noted that "Many of the Montreal cigar stores are operated by women entirely-you even see them dressing the windows." ${ }^{54}$ In 1944 there was a feature article of a father who purchased a retail store for his son, who was in active duty, and which was being operated by his daughter, who revelled in the work. "Shirley is on the job at 7:30 in the morning and she says she is still surprised at the number of men and women on their way to work at this time who stop to buy cigarettes, tobacco, newspapers and magazines. About 10:00 the housewives, out to do their shopping at the nearby stores, start coming into the store. 'I am kept busy all day long,' said Shirley, 'looking after customers and keeping the store and stock in shape. And I never enjoyed anything so much in my life.", On the question of women smokers she said,

I always knew that there were a lot of women and girls that smoked but I had no idea that there were so many of them... [but] men are easier to sell to... and spend money more freely. For instance, if a woman comes in and wants cigarettes with cork tips and I haven't any in the store she will not buy anything else but will leave. A man, on the other hand, is always willing to take another brand and usually they stay and look around a bit. Before they go out, in addition to buying cigarettes, they will have a paper or magazine, perhaps a chocolate bar and very often a soft drink. ${ }^{55}$

This exemplifies the common perception that women's disposable income, even if personally earned, had to be rationed more than men's. Shirley's revelling in her work was also a poignant example of the experiences of many women in the workforce who would soon be displaced by returning soldiers. But independent storekeepers did have some autonomy, and certainly some authority, as evidenced in the women I have labelled "Calamity Janes." When it came to marketing during the War, some brands preferred to retain traditional approaches, such as exotic or Western scenes. One of those brands, Ogden's Fine Cut, portrayed a wagon train with a woman riding shotgun. ${ }^{56}$ This could sometimes echo real life. As noted above, robberies were always a risk for the retail trade. In 1943, when The Journal reported Toronto tobacconist John Whittle's robbery at the hands of thieves with a sawed-off shotgun, Whittle's injury was added by the insult of a companion article, singing the praises of Miss Ruth Woolmer. Woolmer was a 21-year-old United Cigar Store clerk who was not to be trifled with. Also working in Toronto, Woolmer didn't believe in fake gunmen:

It takes more than a hand-in-the-pocket gesture and a verbal command to make her hand over the contents of a cash register. When she suggested the gunman show her the gun, he fled the store. She ran after him and [called the] police constable who chased him and arrested him. "I was a bit scared at the time," Miss Woolmer acknowledged," but I had read too many stories about these fake gun hold-ups and I just thought he might be faking." ${ }^{\circ}$ 
Woolmer was rewarded with her picture in The Journal. Nor was she the only Calamity Clerk to stand up to the outlaws. Miss Irene Brinkmeirer of Windsor, Ontario foiled a second robbery in her store by refusing a gunman's demand to open the cash register. "The man took his hand out of his pocket and walked out of the store." 58

Vancouver storekeepers appeared particularly feisty. Mrs. Patricia Hooper, a grey-haired widow,

'fed up with being held up,' scared away a would-be hold-up man from her small store ... Hardened by her experience with a two-gun bandit two years ago, Mrs Hooper yelled, 'Get out! I am sick of this!' Stampeded by the brave woman's reply to his terse order, the bandit looked at her - and fled. Within a few minutes, police had broadcast the description given by Mrs. Hooper. They picked up a 6 foot suspect near the store. He had a pair of long-nose pliers, but no gun.

Miss Mary A. Kirby was the "maddest woman in town," after two masked bandits robbed her of $\$ 15.00$. "II could choke him!' she muttered, after realizing she had been fooled by a toy gun." 59

Reports of such incidents took place when strong women were hailed for their essential contributions to the national effort. Even girly shots could be disguised as paeans to muscular women: When actress Georgia Carroll was pictured in a bathing suit hanging on a gym rope, the photo was described, "That weaker sex! ... Take a good look at this curvesome gal. It proves beyond a doubt that these women have been whipping themselves into shape for this uprising for some time. In the past they used to do their conditioning under cover but since they have practically proclaimed to the world that they're taking over, they do their body building in public gyms, which, incidentally, is a place where once upon a time they would never dare to put a dainty foot." ${ }^{\circ 0}$

Not only could women be strong, they could be strong consumers. By the Forties, tobacconists were reporting that female customers were responsible for a significant part of their sales. In 1943, Montreal's Max Spizer stated that, "Today the girls run in here and buy their daily package while waiting for the street car to come along to take them to work." The Journal instructed its readers to gear their merchandising practices to the growing female clientele, citing British Tobacco, which reported in 1944 that "women prefer to purchase their smokes and smoking supplies in the small shop" where they receive "personal attention." ${ }^{161}$ Storekeepers were instructed to keep their stores clean: "They are coming into your store daily-airmen, soldiers, sailors, WAAFs, WRENS, CWACs. And don't those girls look chic in their uniforms-especially the CWACs. Buttons polished, shoes shined and generally looking as smart as new whips." ${ }^{2}$ The army cooperated with the tobacco industry for the war effort, targeting both male and female smokers. At the Toronto premiere of the film "Four Jills in a Jeep," CWACs were "presented with 4500 Dunhill cigarettes in front of City Hall recruiting station. The girls then drove to Christie St. Hospital where they handed the cigarettes over to Red Cross Nursing Sisters for distribution among the patients." ${ }^{\prime 3}$ Tobacco advertisers 
aggressively marketed to women smokers during and after the war. Buckingham's double-page spread of 1944 displayed a woman smoking, while Black Cat brand marketed to women with expensive cover shots of young women holding cats and cigarettes. By 1944, Craven A was marketed with a woman in a sexualized pose. ${ }^{64}$

One of the most famous and long-lasting images of the Canadian industry was Macdonald Tobacco's Lassie. Of all cigarette models, and indeed, print advertising in general, Lassie was one of the strongest female images: muscular rather than fashionably thin, staring directly at the viewer, and wearing full Scottish regalia. By 1943, Lassie had enlisted, and was "At the Nation's Service." By 1944, Lassie was at war; with bayonet at the ready, she was one of the few women in active combat. By September 1945, however, Lassie was out of uniform once again (Figure 5). ${ }^{65}$

The success of two decades of marketing was evident by the end of the war, with the publication of an American study, "Are Women Taking Over?" which claimed that, "women are smoking 3 times as many cigarettes as men, that most women use a pack a day, and that they like to buy perfumed cigarettes from male clerks. [This] means a change in the tobacco store with 'more merchandise with feminine appeal' packing the shelves to keep the women happy. The survey ... came up with the following statistics: Women smoke $68 \%$ of all cigarettes made; $76 \%$ of women smokers use a pack a day; $64 \%$ are married; $59 \%$ have been smoking for 4 to 6 years, and all prefer male sales clerks. ${ }^{966}$

Figure 5. Lassie at War

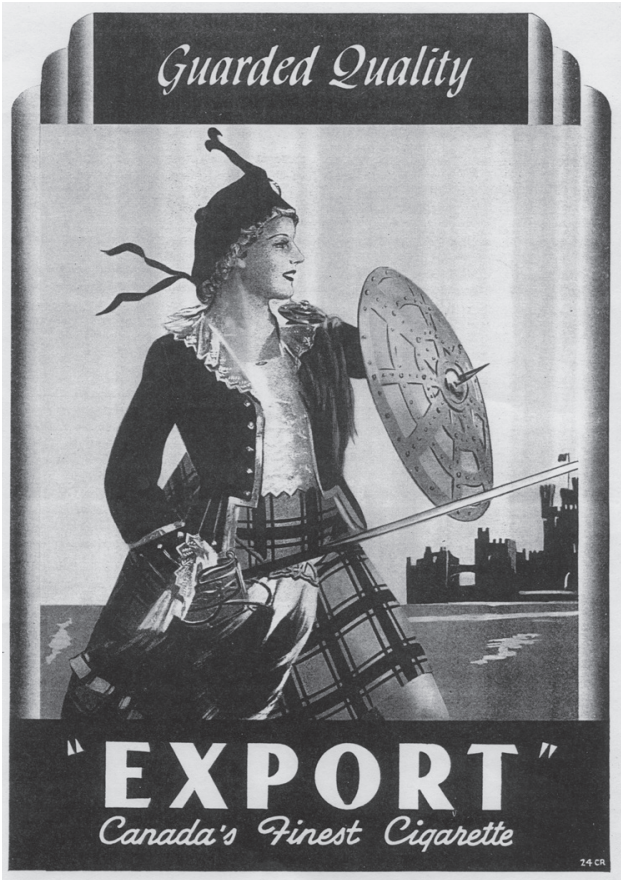


All of this female smoking did not go unnoticed or without male complaints, primarily revolving around competition for public spaces. In a flurry of letters to a Montreal newspaper, male smokers groused over the way female smoking "delays the service in restaurants. Women who enjoy the afterdinner smoke have countered by replying that if some woman wants to smoke a cigarette or two while she waits for her soup, she should be quite free to do so. The feminine reply to men letter writers who insist that the female does not know how to smoke is that if there be any fault it is due entirely to the male sex by whom they were taught the now enjoyable habit." ${ }^{67}$

In the post-war years, women continued to be targets of aggressive marketing. Most of the issues in the late forties had both front and back covers advertising female brands, such as Sweet Caporals, Black Cat or Gold Flake. Yet most of these images increasingly were confined within a passively domestic or glamorous (rather than independent or working) setting. ${ }^{68}$ There were numerous pictures of a man lighting a woman's cigarette, offering her a match, or being in the forefront or dominant position in the picture. ${ }^{69}$ The glamour of advertisements from the twenties and thirties was revived by Vogue cigarette papers, whose logo of a flapper's head directly referenced the fashion magazine's interwar imagery, and Gold Flake, "the cigarette of good taste," whose elegant fashion models, with or without purebreds, copied contemporaneous Lucky Strike campaigns as well as florid Vogue language. ${ }^{70}$ That smoking was refined behaviour was exemplified in a photograph of Princess Elizabeth's elegant desk, where arrows were provided pointing to the telltale, ornate cigarette box and ashtray. ${ }^{71}$ At the other end of the spectrum, postwar ads increasingly were eroticized. When the Sweet Caporal mascot traded her army uniform for her traditional majorette costume, her red lips blowing smoke rings promised, "Yours... for Smoking Pleasure."72 Similarly, a 1948 cover ad for Winchester Cigarettes featured a young woman reclining on a hammock, offering the reader to "Smoke One of Mine..."

Accessories such as lighters shaped like lipsticks or elaborately crafted "Queen Anne" models were marketed to women. The "Pencil-Lighter" ads featured a woman in a passive role; she was lighting a cigarette, while a man was writing. In an evocative ad for Eddy Matches, the pioneer woman was pictured lighting a stove, while the modern woman has her cigarette lit by a man. Certainly the modern woman had an easier time of it, yet the pioneer woman's life was more active. In similar fashion, women smokers in the postwar world were denigrated as careless housewives. In an ad for a cigarette holder, the text read, "Conflagrations sometimes result from women leaving cigarettes for a 'moment' while they answer the doorbell. The resultant gossip with a neighbour gives ample time for a fire to get well started." ${ }^{\prime 4}$

Women might have been careless and passive, but they were appreciated as good shoppers. In an advertisement for Cellophane, the housewife "starred in a $\$ 500,000,000$ role... It's her needs which make the cash registers ring... Her burning impulses which keep products moving off store shelves." Not only 
were women not expected to earn their own salaries in the postwar world, but as consumers and spenders of their husbands' salaries, the expectations were that their "needs" and "impulses" would better feed the economy. As noted in the female storekeeper's assessment of the woman shopper, the working woman penny-pinched more than the working man. As in other magazines, non-tobacco ads displayed an idealized female domestic setting where a woman smilingly sprayed her kitchen with DDT, the "Handy Insecticide Bomb," "harmless to human beings," or, in apron and high heels, painted her kitchen chair. ${ }^{75}$

Despite the increase in female smokers, the industry encountered notable marketing failures, such as the unsuccessful attempts to interest women into smoking cigars and pipes. In "Quick, Jeeves, an Aspirin" The Journal echoed the 1920s public relations techniques of Edward Bernays and Lucky Strikes by printing a 'candid' photograph of a young woman smoking a cigar, with accompanying facetious text that similarly echoed earlier "calls to freedom."

The so-called weaker sex have been advancing so fast the last few years that a dominating male is practically a thing of the past. But this is the climax! We didn't mind them wearing our clothes. We were glad to see them smoking cigarettes. We didn't complain about them driving the trucks and street cars. But to smoke our cigars in these days of shortages is going too far! Comes the Revolution! This young lady - and more like her-are reported to be taking to cigars in preference to cigarettes. Do we have to take this lying down? In Arms, Men, In Arms!!’”6

Similar photos were printed in 1945 and 1946, while an article in 1947 "attested" to the popularity of cigars for women (Figure 6). One Toronto tobacconist estimated that "There were easily 200 or 300 lady cigar smokers in the city. Cigar smokers themselves, most old-time tobacconists tend to describe the feminine Havana addicts as 'lady' cigar smokers. It's a matter of temperament, said one. Like men, it's the moderate thoughtful epicurean personality that likes cigars - cigarettes are just a bad habit." 77

Simultaneous to this campaign was a move to attract women to pipes. Articles about historical British figures who smoked "small feminine pipes," and reports of applications filed at the American Patent Office for ornamental pipes were provided as support for the expansion (or diversion) of women's smoking habits into that market. ${ }^{78}$ As in the case of cigars, however, the other forms of tobacco consumption did not make a great impression, although the later marketing of the "cigarello," or small cigar, was another attempt to change female smoking habits.

\section{Post-War Adjustments}

As the popular post-war film, "The Best Years of Their Lives" recounted, the end of hostilities often meant serious readjustments for the veterans, their families, and the community at large. The Journal reflected this both overtly in its advertisements and indirectly in its articles and humour. By September 1945, 
Figure 6. "Quick, Jeeves, an Aspirin"

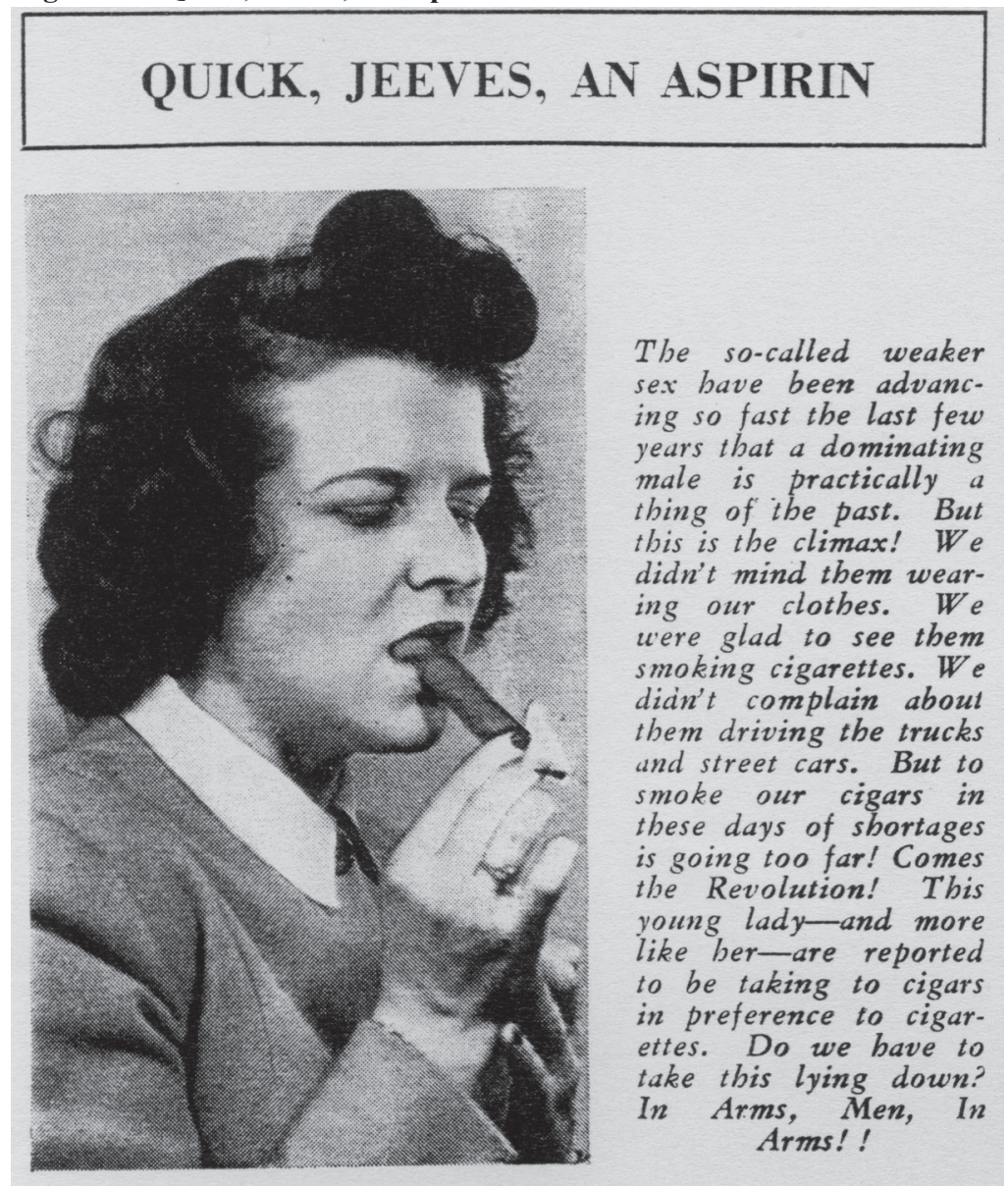

veterans were beginning to supplant women smokers for graphic attention. A double-spread Victory Bond advertisements featured a young man showing off his muscles, while the Sweet Caporals woman smoker saluted "those who wear the [General Service (veteran's)] badge." By 1945, the Sweet Caps girl was a tiny figure in the corner of a domestic scene in which a husband (but not his wife) is holding a cigarette: "He's home again and it's Sweet Caps... Like all Canada's fighting men, he's home to carry out his ideas... to face the future with confidence." Featuring the husband as smoker correspondingly diminished the status of the wife, which underlined the association of female smoking with freedom and autonomy. ${ }^{79}$ The visual trope of the tiny Sweet Caps woman in the background also had resonance as a soldier's memory of sexual freedom "over there" ("Mademoiselle from Armentieres, Parlezvous?"). Soldiers' nostalgia also was used as a marketing tool as army surplus was reconfigured into consumer products. In 1945, Ultima smoking accesso- 
ries included "humidors, cigarette boxes and lighters made from actual shell and cartridge cases." The Table Shellighter was "an actual $20 \mathrm{~mm}$. A.A. Shell. The type that blasted the German Luftwaffe from the skies of Europe." 80

The abrupt demobilization of the majority of middle-class women from the labour force back into domesticity may have not occurred without complaints. Tobacco consumption in the home frequently was alluded to as a bone of contention between husbands and wives. American advice columnist Dorothy Dix instructed her female readers to "let him smoke... It is nagging when wife reminds her husband every time he lights a cigarette... what an extravagance the use of tobacco is, and how injurious it is to the nerves, or how it scents up the curtains... After all, a man does not marry to get somebody to correct him." $" 11$

It was striking how quickly brave troops and veterans were transformed into hen-pecked husbands. In 1946, there was a series of ads for Old Virginia Tobacco, in which a middle-aged husband hides from his wife to avoid chores and smoke in peace. Likewise, in a "Smokescreams" cartoon, a housewife angry with husband dropping ashes yells "Hubert! You sell plenty of ashtrays down at your cigar store! Why in the world don't you use them at home?" A street tableau was described of a "meek little type of guy pushing a baby carriage, with his battle and strife towering over him and a flock of his children... lagging behind." For readers who were fed up with their "battle and strife," there was always "hopeful" humour: "On a moss-grown tombstone was found the following: Here lies my wife, Samantha Proctor, Who ketched cold and wouldn't doctor. She couldn't' stay, she had to go-Praise God, from whom all blessings flow." $\$ 2$

\section{Marketing to Children}

For some marketers, baby carriages represented potential consumers. One of the most problematic aspects of the tobacco trade was (and is) the targeting of children. The $19^{\text {th }}$ century anti-tobacco movement had focussed upon children smoking as indications both of the evils of tobacco and of juvenile delinquency. ${ }^{83}$ There was legislation against the sale of tobacco to minors; yet there was also evidence that such sales occurred and indeed were encouraged. Take for instance Father's Day sales, or, as The Journal put it, "the Saturday before is a second Christmas Eve." In two issues prior to Father's Day, full page display posters were printed honouring "Dad-Defender of the Canadian Home," with children presenting cigarette packages to their uniformed father ${ }^{84}$ Although these campaigns were directed to sale for adult consumption, they encouraged children to feel welcome in tobacco shops, to feel comfortable buying and handling tobacco, and to honour, and ultimately emulate, their smoking parent(s). ${ }^{85}$

Wartime domestic conditions may have accelerated children's access to and consumption of tobacco. That societal controls over children's behaviour were loosening was evident in the humour: Officer, to man walking up and down 
outside a house at 2 a.m.: "What are you doing here." Man: "I've lost my key, officer, and I'm waiting for my children to come home and let me in." Childhood smoking was often portrayed at a safely foreign distance. In a Smokers of the World photograph featuring a Royal Army Medical Corpsman in Salerno, one of the Italian labourers looking on, and smoking a cigarette, appeared to be about ten years old (Figure 7). There were similar post-war items, such as the finding that 80 percent of Dutch boys smoked before the age of eleven; 30 percent of whom had started before they were nine. One of the youngest smokers cited was a five year old Culross, Scotland boy who "won fame as a three year old through his affection for a clay pipe [and] has now achieved the ambition of many smokers by conquering the tobacco habit. As a three year old he smoked fairly consistently and seemed to enjoy his 'Clay.' But his

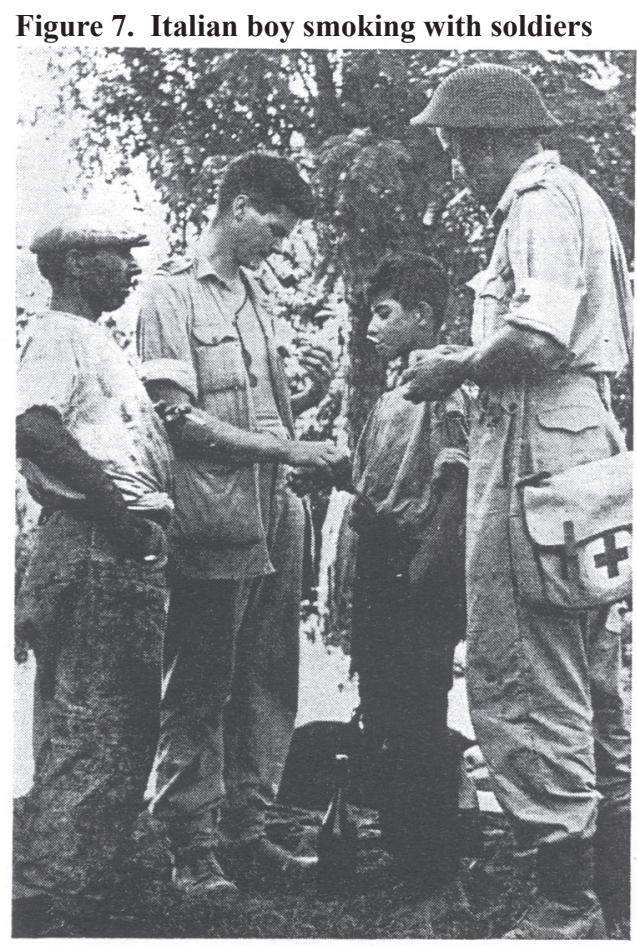

school teacher had other ideas and banned tobacco during school times. As a result of this ban Willie has gradually deserted his pipe even after school hours and shows no sign of returning." 86

In the post-war world, the marketing of tobacco to children and teenagers was more blatant. ${ }^{87}$ A Smoker of the World was Turhan Bey, a singer popular with [teenaged] bobby soxers. In a new feature, "Sideline Parade," nontobacco products were highlighted, including toys such as a Disney Bambi doorstop. The Sweet Caps ad of 1946 featured a very young male skier. In the marketing feature, "Dan Doit," the model retailer dreamed of a Father's Day 
Plan, in which young children lined up at the counter demanding, "I wanna cigar! I'll try a Flat 50! Gimme a Pack of Cigarettes" (Figure 8). A news item on Canadian cigarette consumption statistics stated that cigarette smokers "are also recruited from school pupils of both sexes, although it is to be hoped that girls of school age are not very numerous in this category." Even this faint remonstration (boys apparently were expected to smoke) was countered by the following lines, which recounted the Lucky Strikes public relations stunts of the 1920s: "Smoking among women of fashion in their homes had begun much earlier. It had come in rather later than the use of cosmetics... While old men in the nineties of the last century were asking their younger acquaintances if they 'knew any nice women who smoked,' the abhorred habit was making steady progress." Clearly opposition to smoking among young girls was to be similarly regarded as anti-modern. Further defence of smoking among young people was made by a letter writer to the Family Herald and Weekly Star, and reprinted in The Journal: "Loafing and idleness are not due to tobacco but improper training of children by their parents. Do not blame tobacco for selfishness and inconsideration." ${ }^{88}$

Selling to minors had been targeted by anti-tobacco advocates and church groups for decades, and reflected the reality of youth consumption. In 1948, Winnipeg Police acted upon a complaint by the General Ministerial Association and began enforcing municipal regulations against selling to minors under the age of 16. Although fines ranged from $\$ 10$ for a first violation to $\$ 100$ for a third, there were clearly monetary advantages to flouting the law. Certainly it was not a hidden practice, although The Journal provided contradictory messages. In a 1949 cartoon, a tobacconist was showing off a child-sized barn with smoke wafting from the rear: "Some of our younger customers like to try out their first smoke behind it" (Figure 9). In the same year, two juxtaposed news item demonstrated tobacconists' manoeuvres to entice children into their shops. One retailer created identity cards to adult patrons, authorizing their children to purchase cigarette packages for them, but supposedly preventing them from "indulging a bit themselves," while the other issued piggy banks for children to save their pennies to use towards the purchase of tobacco products for loved ones. ${ }^{89}$ "Individuals" carting piggy banks on wagons must have been very young indeed.

By 1948, "pre-married" young women were portrayed in various action activities while smoking, including skiing, horse jumping, picnicking, and cycling. ${ }^{90}$ Player's also displayed a teenaged male golfer. In 1948, The Journal also featured "back to school" promotions, which included several girls in the photographs. Finally, in 1949, there was a charming photograph of 10-weekold Henry A. Simon, new heir to H. Simon \& Sons Ltd. With his hand firmly clutching a Tuero cigar in an aluminum tube, young Henry proclaimed his tobacco future. ${ }^{91}$ 
Figure 8. Dan “Dreams Up" Father's Day Plan

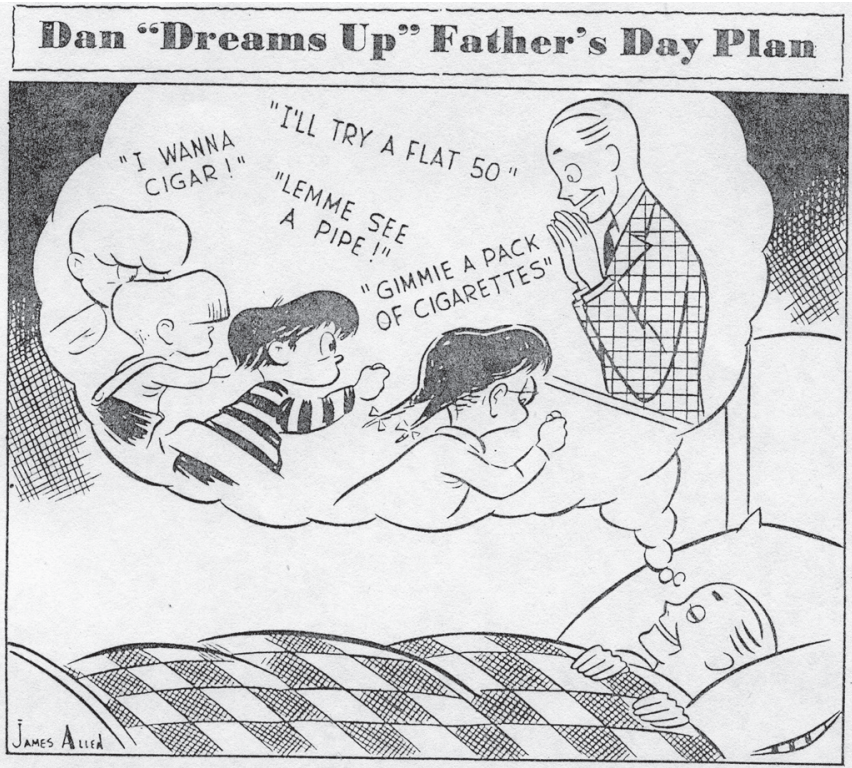

Figure 9. "Some of our younger customers like to try out their first smoke behind it."

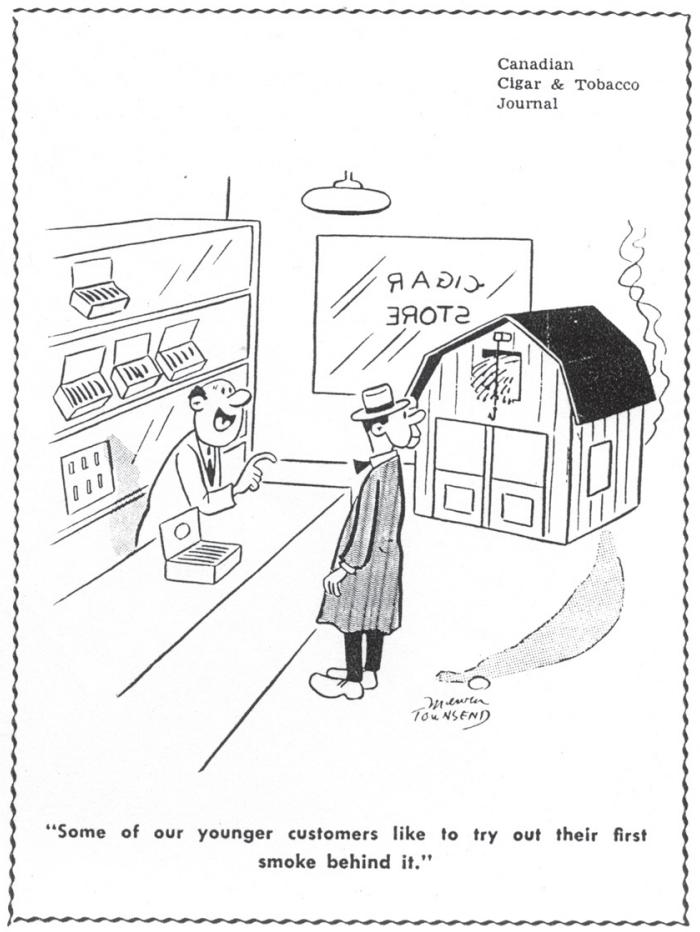




\section{Conclusion $^{92}$}

What does this snapshot of The Canadian Cigar and Tobacco Journal reveal? Canadian cities were bustling with energy, as full employment drew consumers into shops while rationing, taxation and worry over loved ones overseas tempered the excitement. Tobacco manufacturing, sales and consumption permeated all levels of the Canadian economy and society in the forties. Cigarette smoking became normalized behaviour for women as well as men, and the war would provide the apex of its positive representation. Women zestfully partook of their increased economic and public opportunities, and these were reflected in the ads, articles and photos of the wartime issues. Very quickly, however, even before the final Japanese surrender, women disappeared from the ads and text, or were relegated in the backgrounds and domestic scenes. They might still have maintained active public and economic roles in fact, but highly diminished ones in The Journal's imagery. They were replaced not only by their returning husbands, but by their children, targeted by post-war manufacturers and advertisers as the new market for tobacco as well as other products. The tedious, financially uncertain, occasionally dangerous world of the urban storekeeper rendered the occupation a province for immigrants and ethnic minorities (as it does today), as the place of Jews within The Journal's pages revealed a marginalized ethnic group on the cusp of increased socio-economic integration. And tobacco played a role in that integration, as it played for the shop girl sweeping the front stoop, or the world leaders planning the re-conquest of Europe. How did the industry view the forties? We will conclude with The Journal's last word of 1949: "Canadians smoke about $1,700,000,000$ cigarettes per month—a new record." ${ }^{\circ 3}$

\section{Malaspina University College \\ warshc@mala.bc.ca}

\section{List OF FigURES}

All references are to The Canadian Cigar and Tobacco Journal [The Journal]

1. WRENs in a Player's Ad. "Meet the Navy," The Journal 49 (October 1943), front cover.

2. Yalta Ashtray-Smokers of the World. "Smokers of the World: the Cigarette is Out," The Journal 51 (May 1945), 6.

3. Women making wartime cigarettes. "Smokes-For the Men Behind the Guns," The Journal 50 (February 1944), 8.

4. Rock City tobacco factory women. The Journal 53 (March 1947), 22.

5. Lassie at War. "Export: Guarded Quality," The Journal 49 (August 1943), 3.

6. "Quick, Jeeves, an Aspirin," The Journal 50 (April 1944), 5.

7. Italian boy smoking with soldiers. "Smokers of the World," The Journal 50 (January 1944), 8.

8. "Dan 'Dreams Up' Father's Day Plan,” The Journal 52 (May 1946), 22.

9."Some of our younger customers like to try out their first smoke behind it." The Journal 55 (April 1949), 35.

\section{ENDNOTES}

I would like to thank Veronica Strong-Boag and Michael Bliss for their comments, and Jeff Krasnick for his memories. This research was supported by grants from SSHRC/Canadian Tobacco 
Research Institute and Malaspina University-College.

1. Jarrett Rudy used The Journal in preparing his fine study, The Freedom to Smoke: Tobacco Consumption and Identity (Montreal: McGill-Queen's University Press, 2005).

2. Stanton A. Glantz, The Cigarette Papers (Berkeley: University of California Press, 1996).

3. Although World War I accelerated mass male consumption of cigarettes, due in no small part to the free distribution of cigarette rations to troops, female smoking was not considered entirely respectable until the beginning of the thirties.

4. Jack Gerald Krasnick (1922-1986). I occasionally will refer to relevant aspects of his life in the notes.

5. In 1941, there were 63,721 Jews in Montreal and 49,046 in Toronto, according to religious identification in the Canadian Census. See Gerald Tulchinsky, Branching Out: The Transformation of the Canadian Jewish Community (Toronto: Stoddart, 1998), 357-8.

6. My father ran Shaffran's Ltd, a wholesale grocery flourishing in Montreal from the twenties until the post-Referendum depression of the eighties. Founded by his brother-in-law, Isadore Shaffran, the company sold Prairie hay and straw to builders to cover construction sites in winter, and packaged food, dry goods, notions and tobacco to the Jewish, Greek, Portuguese, Italian and other small grocery (or dépanneur) owners in Montreal. The small sales department was Jewish and male, the bookkeeper and receptionist female, the truck drivers were French, the food companies were Anglo-Canadian or American multinationals - the classic Montreal ethno-corporate structure. There were larger provincial wholesalers, but Shaffran's customers preferred the personalized service (Dad could curse in most European languages) and easier credit terms.

7. The Journal 49 (January 1943), 27. A wedding announcement was published of one of the Simon sons, in uniform, in 1944. The Journal 50 (May 1944), 6.

8. His legacies include the Jewish General Hospital and the Young Men's/Young Women's Hebrew Association (YM/YWHA).

9. "Toronto Retailer Proves Value of Re-investing Money in Store," The Journal 49 (March 1943), 8-9; Ronald J. Cooke, "Jack Lewis' Name is Synonymous with Fine Tobaccos in Montreal," The Journal 49 (July 1943), 8; "Rouyn Cigar Shop Under New Owner," The Journal 50 (January 1944), 18. Apparently Rouyn wasn't ready for Cohen's Cigar Shop; "Frank Cohen sells out to Mrs. Malouf," The Journal 51 (September 1945), 22.

10. The Journal 49 (October 1943), 10; The Journal 52 (July 1946), 32; The Journal 54 (May 1948), 16; The Journal 54 (July 1948), 9.

11. Shaffran's had a number of break-ins, including a night-time incident when miscreants smashed through a brick wall to steal only (what else?) cigarette cartons. There were also at least two armed robberies. After the first, Dad installed a silent alarm to the police station. At the second hold-up, his hand was only inches from the button, but he couldn't move. We all were thankful for that.

12. "Maritime News," The Journal 49 (January 1943), 9; "Northern Ontario News," and "Alberta News," The Journal 49 (March 1943), 12, 14; "Footprints lead police to thieves," The Journal 49 (February 1943), 5; The Journal 50 (January 1944), 7.

13. Harry Grevas, who ran a cigar stand in Vancouver, was convicted for betting on horse races. The Journal 49 (January 1943), 10. Two men and a woman were fined in Brantford, Ontario in 1943 for having slot machines on a lunch counter. "Western Ontario News," The Journal 49 (February 1943), 10. See Rudy, Freedom to Smoke, 36-37 for gambling and male subculture.

14. My mother, three brothers and I didn't need the Surgeon-General's Report of 1964 to tell us that smoking was lethal; we heard it in the house. The "smoker's cough," so benignly characterized in cigarette ads, was rumbling, seemingly endless paroxysms, which sounded as if Dad would spit out his lungs at any time. We all hid in our rooms until they were over, because the Angel of Death was present.

15. Ian Tyrrell, "Before the Surgeon-General's Report: Public Discourse in Australia over Tobacco Addiction to 1964," Australian Journal of Politics and History 44 (1998): 177-90.

16. Statistics Canada. Historical Statistics of Canada. Section B: Vital Statistics and Health, Series B65-74: Life Expectancy by sex, at selected ages, Canada, Census years 1871-1971, comp. R.D. Fraser.

17. The Journal 49 (January 1943), 5, 9; "Lengthy illnesses" were often euphemisms for 
cancer. The Journal 50 (May 1944), 5; The Journal 51 (August 1945), 9; The Journal 52 (January 1946), 7; The Journal 52 (June 1946), 9; The Journal 55 (October 1949), 10.

18. "Cigar Smoking Runner Puffs Through Again,” The Journal 54 (June 1948), 8.

19. "Century Old Smoker," The Journal 49 (October 1943), 30; The Journal 52 (September 1946), 10; The Journal 52 (May 1946), 8; The Journal 52 (May 1946), 38.

20. Robert H. Feldt, "The Truth about Tobacco," American Mercury, was quoted in "Misleading Smoking Theories Dispelled by Doctor-Scientist," The Journal 49 (November 1943), 6; "Nicotine is Made Harmless by Body," The Journal 50 (January 1944), 16; "Tobacco Leaf Extract Aids in Fighting High Blood Pressure," The Journal 52 (March 1946), 8.

21. See the cartoon: doctor leaving with 4 cigars. Man in bed, nurse standing over him: "Oh boy! Fifty centers! That sure was a great idea of mine to forbid him to smoke." The Journal 52 (August 1946), 36; "Smokers Not So Bad After All," The Journal 52 (March 1946), 20. For smoking among doctors, see Rudy, Freedom to Smoke, 23-27.

22. “Are you kiddin' Doc?" The Journal 52 (March 1946), 34; Craven A advertisement, The Journal 52 (March 1946), back cover.

23. Irvin S. Koll, "Is Tobacco Injurious?" The Journal 55 (March 1949), 20.

24. For more on concern for avoiding public display in smoking, see Penny Tinkler, "Refinement and Respectable Consumption: The Acceptable Face of Women's Smoking in Britain, 1918-1970," Gender \& History 15 (August 2003): 342-60.

25. Gerry Krasnick enlisted in the Canadian Contingent of the RAF when the war broke out. $\mathrm{He}$ trained as a radar technician at the University of Western Ontario military facility, and was stationed in England and North Africa. From Montreal's working-class Jewish ghetto he found himself, like so many other young men and women, catapulted into world history. He witnessed a massive rally for Mahatma Ghandi in South Africa, and his division met Rommel's forces in Libya and Morocco. Every mid-afternoon, troop movements through the North African desert were halted as his commanding officer insisted that British civilization should prevail and all should have tea. "There was so much sand in the cup, the spoon stood on end." Gerry was promoted to sergeant for a short time, but was demoted again when he threw live electrical wires at a British officer who made anti-Semitic remarks. The officer was reprimanded. Gerry made some history of his own, when he and other Jewish and non-Jewish soldiers smuggled guns to the Haganah [freedom fighters] in Palestine, who fought the British Mandate authorities blocking the immigration of refugees from the Holocaust.

26. The Journal 49 (January 1943), p 3; The Journal 49 (January 1943), 17; The Journal 49 (February 1943), front cover. See also The Journal 49 (May 1943), front cover; Ronson advertisement, The Journal 49 (February 1943), 11; Eddy Matches advertisement, The Journal 49 (March 1943), 13; The Journal 49 (March 1943), front cover; Kool advertisement The Journal 49 (May 1943), 16-17.

27. "A Picture of Contentment: Smoke Buckingham and Smile [advertisement]," The Journal 49 (January 1943), 14-15; "Player's Please [advertisement]," The Journal 49 (August 1943), front cover; See also Player's advertisement, The Journal 49 (December 1943), front cover.

28. "News from B.C.," The Journal 49 (January 1943), 10; "Northern Ontario News," The Journal 49 (March 1943), 12.

29. The Journal 50 (February 1944), 8-9.

30. The Journal 49 (July 1943), 12; "He's alive because he smokes," The Journal 50 (January 1944), 6; "Smokes proved a solace to inmate," The Journal 50 (January 1944), 10; "Smokers of the World," The Journal 49 (March 1943), 7. See also "Smokers of the World," The Journal 49 (February 1943), 10; The Journal 50 (April 1944), 7; "Nazi Preferred U.S. Smokes," Star and Stripes, quoted in The Journal 50 (August 1944), 30.

31. See Richard Klein, Cigarettes are Sublime (Durham: Duke University Press, 1993) for the cigarette's positive imagery during wartime.

32. "Post War Planning for Dollar Sales and Profits," The Journal 50 (January 1944), 12.

33. In my Dad's Churchill Period, when he replaced cigarettes with cigars to lower his consumption, there was nothing to compete with the nausea of our weekend road trips in minus 30 degree weather, with the windows shut tight, the heater blasting, and four kids crammed in a rear wheel-drive Chrysler station wagon, as he puffed away contentedly on his El Productos. 
34. "Photo minus the cigar," The Journal 50 (May 1944), 20; The Journal 49 (August 1943), 9.

35. "Writer says Churchill No Cigar Connossieur," The Journal 49 (December 1943), 10; The Journal 49 (December 1943), 10.

36. The Journal 49 (November 1943), 5; The Journal 50 (April 1944), 22.

37. Published soon after FDR's death, the caption poignantly reads, "The Cigarette is out."

38. "Refuse FDR a Smoke," The Journal 50 (March 1944), 5; "Smokers of the World," The Journal 51 (May 1945), 7; The Journal, 51 (December 1945), 9.

39. "Crooner's Pipe Collection Lost," and "Cigar Smoking Parrot is Hero of New Walt Disney Picture," The Journal 49 (February 1943), 9.

40. The CIA sponsored an edition of "Can You Top This?" a game show where three comedians told jokes about a subject. That night, the subject was cigars; the event was considered a "most effective type of cigar propaganda." "Can You Top This? Programme Joins Cigar Promotions Parade," The Journal 49 (February 1943), 10; "Can You Top This? Cigar Program Stirs Wide Comment," The Journal 49 (March 1943), 12; Harold Hefferman, Chicago Daily News is quoted in "Charles Coburn, Popular Cigar Ambassador, Stars in Gay Movie," The Journal 49 (May 1943), 22.

41. The Journal 49 (July 1943), 16; The Journal 49 (October 1943), front cover; The Journal 50 (May 1944), 7.

42. Shaffran's certainly was a male space, with only two permanent female employees, a girly calendar on the wall, and two non-gender-designated, hygienically challenged washrooms. When Dad posted a Woman sign on one of them the summer I worked there, the truck drivers would have none of it, and the sign came off after a week.

43. See for instance, "Mapy Cortes of RKO's 'Seven Days Leave,"'The Journal 49 (January 1943), 10; "First Exclusive Shot of Miss St. Nick [Jane Randolph of RKO], The Journal 49 (January 1943), 13.

44. "An Advertisement from NSS," The Journal 49 (January 1943), 20.

45. The Journal 49 (April 1943), 14; The Journal 50 (April 1944), 22. A particularly bizarre photograph was of movie star Betty Grable in blackface. See The Journal 49 (April 1943), 14.

46. There was a young lady from Kent/ Who said that she knew what it meant/ When men asked her to dine/ Gave her cocktails and wine/ She knew what it meant-but she went." The Journal 49 (January 1943), 10.

47. The Journal 49 (April 1943), 23.

48. The Journal 49, (August 1943), 9; The Journal 49 (September 1943), 12; The Journal, 49, 10 (October 1943), 30.

49. The Journal 50 (March 1944), 14; The Journal 50 (February 1944), 30.

50. The Journal 49 (January 1943), 6-7; The Journal 49 (December 1943), 8; "Smokes for the men behind the guns," The Journal, 50 (February 1944), 8-9. See also B. Houde \& Grothe's 25 year service photo, picturing 16 men and 23 women. The Journal 50 (June 1944), 7.

51. "How Cigars are Made," The Journal 52 (February 1946), 14. See also "The Story of Pipes," The Journal 52 (September 1946), 16-17 which shows a woman crafting a pipe.

52. The Journal 52 (December 1946), 9; The Journal 53 (March 1947), 10. An exception was a western wholesale firm whose office pictured two women out of five clerks. The Journal 53 (March 1947), 18.

53. "The Story of Cigarettes: How they are Manufactured," The Journal 53 (April 1947), 20; The Journal 54 (April 1948), 35.

54. "Western Ontario News," The Journal 49 (January 1943), 13; See also The Journal 49 (March 1943), 18; The Journal 49 (April 1943), 14; Ronald J. Cooke, "Jack Lewis' Name is Synonymous with Fine Tobaccos in Montreal," The Journal 49 (July 1943), 8.

55. "Father purchases smart retail store for son now on active service," The Journal 50 (November 1944), 10.

56. MacDonald's tobacco portrayed pyramids, camels and Bedouins, reflecting associations of Egyptian blends with elite smokers. The Journal 49 (February 1943), 3. Ogden's Fine Cut advertisement, The Journal 49 (February 1943), 4.

57. The Journal 49 (January 1943), 9. See also "Thief Steals 70 cents and Smokes in B.C." 
The Journal 49 (January 1943), 16; "Female Clerk Calls Gunman's Bluff-Holdup Attempt Fails," The Journal 49 (January 1943), 9.

58. The Journal 54 (January 1948), 34.

59. The Journal 53 (February 1947), 10; The Journal 53 (March 1947), 10. See also The Journal 49 (September 1943), 12; and "Woman customer foils thieves," The Journal 52 (April 1946), 9.

60. The Journal 50 (June 1944), 22.

61. The Journal 49 (December 1943), 14; "Trend is toward the smaller dealer," The Journal 50 (January 1944), 10.

62. WAAFs were the Women's Auxiliary Air Force; WRENs were the Women's Royal Canadian Naval Force; CWACs were the Canadian Women's Army Corps; "Grip Toter," The Journal 49 (April 1943), 9.

63. The Journal 50 (June 1944), 12; The Journal 50 (June 1944), 14.

64. The Journal 49 (January 1943), 6; The Journal 50 (July 1944), 14-15; "Give me Black Cat Every Time!" The Journal 49 (March 1943), 32. See also The Journal 49 (April 1943), back cover; The Journal 49 (May 1943), back cover; The Journal 50 (March 1944), back cover.

65. Macdonald's advertisement, The Journal 49 (July 1943), 3; Lassie was saluting a year later. The Journal 50 (March 1944), 23; The Journal 50 (October 1944), 3; The Journal 50 (November 1944), 3; The Journal 51 (September 1945), 3.

66. “Are Women Taking Over?” The Journal 52 (March 1946), 10.

67. The Journal 50 (March 1944), 16. Similar observations were made by Rudy, Freedom to Smoke, 164-66.

68. I note parallels in alcohol advertising in the forties and fifties in Cheryl Krasnick Warsh, "Smoke and Mirrors: Gender Representation in North American Tobacco and Alcohol Advertisements before 1950," Histoire sociale/ Social History 31 (November 1998), 213.

69. See for instance "Buchmann Spark Wheel," The Journal 51 (December 1945), 13; Sweet Caporals advertisement, The Journal 54 (December 1948), cover.

70. The Journal 52 (January 1946), 15. One Gold Flake ad read: "Rust brown swagger rolling felt brim - a heavy mesh veil tossed alluringly over the shoulder of the neck line.' Designed by Lily Dache," The Journal 52 (October 1946), 2. For more on tobacco and Vogue, see Cheryl Krasnick Warsh and Penny Tinkler, "In Vogue: North American and British Representations of Women Smokers in Vogue, 1920s-1960s," Canadian Bulletin of Medical History/ Bulletin canadien d'histoire de la médicine 24 (2007), in press.

71. "Rumor Princesses Smoke Causes Eyebrow Raising," The Journal 55 (December 1949), 8.

72. The Journal 53 (January 1947), 6.

73. Winchester Cigarettes advertisement, The Journal 54 (August 1948), front cover.

74. Dworkin lighters advertisement, The Journal 52 (April 1946), 5. Ronson advertisement, The Journal 52 (February 1946), 11; Ronson advertisement, The Journal 55 (October 1949), 13; The Journal 52 (December 1946), 41; Eddy Matches advertisement, The Journal 53 (March 1947), 7; The Journal 54 (May 1948), 36.

75. The Journal 51 (October 1945), 5; The Journal 51 (October 1945), 5; Bridgeport Aer-a-sol Insecticide Bomb advertisement, The Journal 52 (April 1946), 16, and Continental Can advertisement, 17. These images have been noted as well in Valerie Korinek, Roughing it in the Suburbs: Reading Chatelaine Magazine in the Fifties and Sixties (Toronto: University of Toronto Press, 2000), 40-41.

76. "Quick, Jeeves, an Aspirin," The Journal 50 (April 1944), 5. On the American PR campaigns of the twenties, see Michael Schudson, "Women, Cigarettes and Advertising in the 1920s: A Study in the Sociology of Consumption," in Mass Media Between the Wars: Perceptions of Cultural Tension, 1918-1941 ed. Catherine L. Covert and John D. Stevens, (Syracuse: Syracuse University Press, 1984), 71.

77. The Journal 51 (November 1945), 12. See also The Journal 52 (February 1946), 2; The Journal 53 (February 1947), 10.

78. The Journal 55 (June 1949), 24; The Journal 52 (April 1946), 32.

79. The Journal 51 (September 1945), 4-5, 8; Penny Tinkler and I found similar imagery in the 
postwar treatment of the female smoker in Vogue magazine. See Warsh and Tinkler, "In Vogue."

80. The Journal 51 (September 1945), 29; Table Shellighter advertisement, The Journal 51 (December 1945), 31.

81. "Dorothy Dix says let him smoke," The Journal 50 (February 1944), 14; The Journal 54 (March 1948), 31.

82. The Journal 52 (May 1946), 19; The Journal 52 (August 1946), 29; The Journal 52 (October 1946), 52. See also The Journal 53 (April 1947), 14; The Journal 53 (May 1947), 14; The Journal 55 (January 1949), 35.

83. See Tate, Tobacco Wars, 29-30, 102 and Rudy, Freedom to Smoke, 20-22.

84. "Father's Day Profits are Worth Working For," The Journal 49 (May 1943), 8, 9.

85. When my brother Jeffrey, at age sixteen, worked at Shaffran's, the tobacco company salesman always offered him free samples, which he declined.

86. The Journal 49 (February 1943), 16; "Smokers of the World," The Journal 50 (January 1944), 8; "Unusual Facts of the Use of Tobacco," The Journal 55 (October 1949), 28; "Five-YearOld Deserts his Pipe," The Journal 54 (August 1948), 30.

87. The targeting of the child as consumer in post-war America is discussed in Lizabeth Cohen's fine study, A Consumers' Republic (New York: Alfred A. Knopf, 2003), 318-21, 350.

88. The Journal 51 (November 1945), 9; The Journal 51 (December 1945), 16; The Journal 52 (March 1946), 16; The Journal 52 (March 1946), 11; The Journal 52 (May 1946), 22; "Cigarette Usage in Canada increases 3900\% since 1900," The Journal 52 (September 1946), 28; The Journal 52 (October 1946), 20.

89. The Journal 54 (September 1948), 29; The Journal 55 (April 1949), 35; "Merchandising Manoeuvres," The Journal 55 (June 1949), 34.

90. I assume they are pre-married because there is neither husband nor children in the scenes. Player's advertisement, The Journal 54 (February 1948), 2; Player's advertisement, The Journal 54 (May 1948), 19; Winchester advertisment, The Journal 54 (June 1948), cover; Player's advertisement, The Journal 54 (September 1948), 29.

91. The Journal 54 (June 1948), 13; The Journal 54 (March 1948), 20; The Journal 54 (August 1948), 14; The Journal 55 (January 1949), 8.

92. For our family, the golden age of Montreal ended on February 19th, 1985. Dad had finally decided to leave his beloved city and move with Mum to Victoria, B.C., where my eldest brother Mark lived. He was packing for their trip to scout out the area when he suffered his third heart attack and died. Montreal would not let him go.

93. Moyer, “Along Tobacco Row," The Journal 55 (December 1949), 34. 